\title{
Physiological and cytological aspects of Inga vera subsp. affinis embryos during storage
}

\author{
José M.R. Faria ${ }^{1,3, *}$, Lisete C. Davide ${ }^{2}$, Edvaldo A. A. da Silva ${ }^{3}$, Antonio C. Davide ${ }^{3}$, Roselaine \\ C. Pereira ${ }^{2}$, André A.M. van Lammeren ${ }^{4}$ and Henk W.M. Hilhorst ${ }^{1}$ \\ ${ }^{1}$ Laboratory of Plant Physiology, Wageningen University, Arboretumlaan 4, 6703 BD Wageningen, The Netherlands. ${ }^{2}$ Departamento \\ de Biologia, Universidade Federal de Lavras. ${ }^{3}$ Departamento de Ciências Florestais, Universidade Federal de Lavras, CP 3037 , \\ 37200-000, Lavras, MG, Brazil. ${ }^{4}$ Laboratory of Plant Cell Biology, Wageningen University, Arboretumlaan 4, 6703 BD Wageningen, \\ The Netherlands.*Corresponding author:jmfaria@ufla.br
}

Received: 15 November 2006; Returned for revision: 26 February 2007; Accepted: 25 March 2007

The remarkably short storability of recalcitrant seeds has prevented their inclusion in programs of ex situ conservation. The causes of their desiccation sensitivity and rapid decline in viability during storage are not fully elucidated yet. In this study the highly recalcitrant, fully viable embryos of the tree species Inga vera subsp. affinis were stored under various conditions and analyzed physiologically and cytologically at intervals, in order to obtain more insights in their loss of viability during storage. Embryos stored fully hydrated at $5^{\circ} \mathrm{C}$ fully lost viability in $18 \mathrm{~d}$. Sealed storage of partially dehydrated embryos slightly prolonged their viability, with $95 \%$ germination being attained after $14 \mathrm{~d}$ of storage. However, after $30 \mathrm{~d}$ of storage, viability was completely lost. Storage of hydrated embryos in a solution of polyethylene glycol (PEG) at $-1.7 \mathrm{MPa}$ water potential was capable of maintaining high germinability until $30 \mathrm{~d}$ of storage. When added to the PEG solution, abscisic acid showed a strong temperature-dependent interaction, with a positive effect on the longevity of embryos stored at $20^{\circ} \mathrm{C}$ and a negative effect on embryos stored at $5^{\circ} \mathrm{C}$. In any case, embryo viability could be maintained no longer than $50 \mathrm{~d}$. Embryos from seeds collected from the same trees in the following year showed better storability and still attained $45 \%$ germination after $62 \mathrm{~d}$ of storage. Analysis of cellular alterations during storage and viability loss of the embryos showed disappearance of starch granules and various damages to the cells, such as cell wall folding and cytoplasm fragmentation.

Key-words: abscisic acid, polyethylene glycol, recalcitrant seeds, seed conservation

Aspectos fisiológicos e citológicos de embriões de Inga vera subsp. affinis durante o armazenamento: A capacidade reduzida de armazenamento apresentada pelas sementes recalcitrantes tem impedido sua inclusão em programas de conservação $e x$ situ. As causas da rápida queda da viabilidade durante o armazenamento ainda não estão totalmente elucidadas. Visando, portanto, a um melhor entendimento desse comportamento, embriões de sementes recalcitrantes de Inga vera subsp. affinis foram armazenados sob várias condições e avaliados periodicamente com relação a aspectos fisiológicos e citológicos. Embriões armazenados sem secagem, a $5^{\circ} \mathrm{C}$, perderam totalmente a viabilidade em 18 dias. Embriões parcialmente desidratados apresentaram $95 \%$ de germinação após 14 dias de armazenamento em sacos plásticos selados. Entretanto, após 30 dias de armazenamento, a viabilidade foi totalmente perdida. $\mathrm{O}$ armazenamento de embriões sem secagem em solução de polietileno glicol (PEG) a um potencial hídrico de -1,7 MPa foi capaz de manter uma alta capacidade de germinação até 30 dias de armazenamento. Quando adicionado à solução de PEG, o ácido abscísico mostrou uma forte interação com a temperatura de armazenamento, com um efeito positivo na longevidade dos embriões armazenados a $20^{\circ} \mathrm{C}$, porém um efeito negativo nos embriões armazenados a $5^{\circ} \mathrm{C}$. No entanto, em nenhuma condição, a viabilidade dos embriões pôde ser mantida por mais de 50 dias. Embriões de sementes coletadas nas mesmas árvores no ano seguinte mostraram uma melhor capacidade de armazenamento, alcançando $45 \%$ de germinação após 62 dias de armazenamento. A análise de alterações celulares durante o armazenamento dos embriões mostrou o desaparecimento de grânulos de amido e vários danos às células, como dobras na parede celular e fragmentação do citoplasma.

Palavras-chave: ácido abscísico, conservação de sementes, polietileno glicol, sementes recalcitrantes, 


\section{INTRODUCTION}

In recent years, awareness concerning the loss of plant diversity has captured worldwide attention and germplasm conservation has become necessary as a means of maintaining species diversity to prevent genetic erosion (Marzalina and Krishnapillay, 1999). While it is relatively easy to store orthodox and intermediate seeds in the long- and medium-term, respectively (Roberts, 1973; Ellis et al., 1990), one of the greatest challenges for those who deal with seed banks is the conservation of recalcitrant seeds. Recalcitrant seeds are shed with high moisture content, high metabolic activity and their viability is lowered or even totally lost when moisture content is reduced to a certain relatively high value. The refinement of storage techniques for intermediate and recalcitrant seeds is among the key storage research subjects for the future (Smith et al., 2003).

The bad storability of recalcitrant seeds has been widely reported, but the mechanisms involved in seed death during storage are not yet fully elucidated. In general, germinability has been the only parameter used to characterize the loss of viability (e.g., Goldbach, 1979; Tompsett, 1984, 1985; Farrant et al., 1993; Hong and Ellis, 1998; Tompsett and Pritchard, 1998). Although essential for characterizing the recalcitrant behavior, decrease in germination rates does not reveal per se the causes of the poor storability, since it is the end point of several processes occurring within the stored seed, which ultimately lead to seed death.

Because recalcitrant seeds are not desiccationtolerant they must be stored moist (Greggains et al., 2000). However, even in moist conditions, their longevity is short, varying from a few weeks to a few months, depending on the species (Roberts and King, 1980a). One of the possible causes of viability loss of stored recalcitrant seeds is that they remain metabolically active during storage (Pammenter et al., 1994), thereby exhausting the seed's food reserves. Intracellular damages have been reported for hydrated recalcitrant seeds during storage and include degeneration of plastids, disruption of nuclear morphology, spatial disorientation of organelles and collapse of cell wall (Drew et al., 2000).

If metabolism is an underlying cause of the short storage life span, then reducing metabolic rate should extend longevity (Berjak and Pammenter, 2003). One possible approach is to store the seeds in an osmotic medium, such as polyethylene glycol (PEG) with or without the addition of germination inhibitors, such as abscisic acid (ABA) (Tompsett, 1985). Besides slowing down the metabolism, ABA can also induce desiccation tolerance in sensitive seeds and tissues, such as germinated seeds of cucumber (Bruggink and van der Toorn, 1995). Many of the physiological and biochemical changes caused by ABA in developing embryos can also be induced by low osmotic potentials (Bewley and Black, 1994). In cucumber seedlings, chilling tolerance was enhanced by exposing them to osmotic or heat stress, which induced the synthesis of dehydrin-like and heatshock proteins respectively (Kang et al., 2005). Since these two protein families have been associated with desiccation tolerance (Delseny et al., 1994), it is possible that both osmotic and heat stress can also enhance desiccation tolerance in sensitive seeds. Osmotic stress (PEG) is also capable of re-establishing desiccation tolerance in germinated seeds of cucumber (Bruggink and van der Toorn, 1995; Leprince et al., 2000) and Medicago truncatula (Buitink et al., 2003; Faria et al., 2005). Intermittent heat-shock (HS) treatment has been used to improve low-temperature fruit storage of recalcitrant species, such as mango and avocado (Marcellin, 1992). Incubation in PEG, slow drying and heat-shock, independently, were able to increase longevity in primed seeds (Bruggink et al., 1999). It seems therefore that these techniques have the potential to decrease the desiccation sensitivity shown by recalcitrant seeds and/or increase their longevity.

Inga vera subsp. affinis, seeds of which were used in this study, is a leguminous tree species typical of the riparian forests in south-eastern Brazil, and one of the most important species for ecological restoration of those ecosystems. Its seeds are recalcitrant and have one of the worst storabilities known (Bilia et al., 1999; Barbedo and Cicero, 2000; Faria et al., 2004; Andréo et al., 2006). In order to develop storage protocols for recalcitrant seeds a better knowledge of the events associated with storage is mandatory. In the present study the physiological and cytological aspects of $I$. vera embryos during storage under different conditions were characterized. 


\section{MATERIAL AND METHODS}

Plant material: By the time of their natural dispersion, mature fruits of I. uruguensis (a botanical synonym of $I$. vera subsp. affinis) become yellowish (Figliolia and Kageyama, 1994). Mature seeds of Inga were thus obtained from yellowish, soft fruits hand-harvested in January 2004 and January 2005 from 20 adult, healthy trees, growing in riparian forests along the Rio Grande at the surroundings of the city of Lavras $\left(21^{\circ} 09^{\prime} \mathrm{S}, 44^{\circ} 53^{\prime} \mathrm{W}\right.$, 808 m a.s.1.), Minas Gerais State, Brazil. The climate at the site is classified as a transition between Cwb and Cwa, characterized by hot and humid summers with mild and dry winters, according to Köppen's classification (Köppen, 1936). On the same day of fruit collection seeds were manually extracted, processed and sampled for the experiments described below. Seeds were covered by fleshy, aqueous sarcotesta and embryos were fully developed. During processing the seeds, the sarcotesta was removed, which caused removal of the inner layers of the seed coat as well, ending up with the naked embryo. Removal of the sarcotesta was an absolute prerequisite since it is rich in sugars (Figliolia and Kageyama, 1994) which results in excessive growth of microorganisms during storage (Zuniga, 1996) and during germination tests (Bilia et al., 1998).

Assessment of moisture content: Moisture contents (MC) of the embryos were determined gravimetrically on four replications of five embryos by oven drying them for $17 \mathrm{~h}$ at $103^{\circ} \mathrm{C}$ (ISTA, 1996). Moisture contents were calculated as $\mathrm{g} \mathrm{H}_{2} \mathrm{O} \mathrm{g}^{-1} \mathrm{DM}$ (hereafter $\mathrm{g} \mathrm{g}^{-1}$ ). Embryos stored in PEG were opened by separating the cotyledons and washed rapidly before $\mathrm{MC}$ determination, in order to remove PEG residues.

Germination tests: Due to the ovoid shape of the embryos, they were germinated (partially buried) on moistened sand in plastic boxes $(11 \times 11 \times 3.5 \mathrm{~cm})$, at $30^{\circ} \mathrm{C}$ and constant light (Faria et al., 2004). Four replications of 20 embryos were used. Germination was scored daily, with visible growth of the radicle as the criterion for germination. Before being set to germinate, all embryos were surface sterilized by washing in a solution of sodium hypochlorite $(1 \%)$ for $10 \mathrm{~min}$, followed by thorough rinsing in distilled water.

Embryo storage: The storability of I. vera embryos was assessed in 15 treatments, distributed over two experiments, as described below.

Storage Experiment 1: Embryos from seeds collected in January 2004 were placed in a bench top humidity chamber (Hotpack model 435314, Warminster, PA, USA), with running air $\left(43 \%\right.$ relative humidity and $\left.25^{\circ} \mathrm{C}\right)$ and were partially dried, from 1.35 to $1.02 \mathrm{~g} \mathrm{~g}^{-1}$. The embryos were then packed in aluminized plastic bags (light- and air-protected; 150 embryos per bag). Air was removed from the packages by using a vacuum pump until the plastic pressed moderately hard against the embryos. The bags were sealed and stored at 5 and $20^{\circ} \mathrm{C}$, in a refrigerator and an incubator, respectively. This protocol is further referred to as 'sealed storage'. After one week a heat-shock was applied to half of the embryos stored at $5^{\circ} \mathrm{C}$, by transferring the bags to an incubator at $30^{\circ} \mathrm{C}$ and keeping them at this temperature for $24 \mathrm{~h}$, after which they were transferred back to $5^{\circ} \mathrm{C}$. Experiment 1 was thus composed of three treatments (Table 1). Non-stored embryos (control, kept at $20^{\circ} \mathrm{C}$ ) and embryos stored for 14 and $30 \mathrm{~d}$ were sampled for germination test, $\mathrm{MC}$ assessment and cytological studies.

Storage Experiment 2: Embryos from seeds collected in January 2004 were stored with their original moisture content $\left(1.35 \mathrm{~g} \mathrm{~g}^{-1}\right)$, in a single layer in plastic trays $(40 \mathrm{x}$ $25 \times 8 \mathrm{~cm} ; 350$ embryos per tray) containing a solution of polyethylene glycol (PEG 8000; Sigma-Aldrich, Zwijndrecht, The Netherlands) at $-1.7 \mathrm{MPa}$ water potential, enough to slightly cover the embryos. Solutions of PEG were prepared with two abscisic acid (ABA; Sigma-Aldrich, Zwijndrecht, The Netherlands) concentrations (0 and $100 \mathrm{mM})$, based on Barbedo and Cícero (2000). The trays were covered with a plastic sheet to decrease the evaporation and stored at 5 and $20^{\circ} \mathrm{C}$, in a refrigerator and an incubator, respectively, in the dark. After one week, a heat-shock was applied to half of the embryos stored at $5^{\circ} \mathrm{C}$, by transferring the trays to an incubator at $30^{\circ} \mathrm{C}$, in the dark for $24 \mathrm{~h}$, after which they were transferred back to $5^{\circ} \mathrm{C}$. Two weeks after the beginning of storage, half of the stored embryos was removed from the PEG solution, washed, blot-dried, air dried (as in Experiment 1) to ca. $0.64 \mathrm{~g} \mathrm{~g}^{-1}$, to test for a possible decrease in desiccation sensitivity. The value of $0.64 \mathrm{~g} \mathrm{~g}^{-1}$ is around the critical MC for I. vera embryos, which ranges from $0.54 \mathrm{~g} \mathrm{~g}^{-1}$ (Bilia et al., 1999) to $0.7 \mathrm{~g} \mathrm{~g}^{-1}$ 
Table 1. Storage of Inga vera embryos after partial dehydration (Experiment 1) or in PEG solution (Experiment 2), with or without ABA, heat-shock or dehydration in combination with sealed storage, as indicated by the plus and minus signs, respectively.

\begin{tabular}{|c|c|c|c|c|}
\hline Treatment & $\begin{array}{l}\text { Temperature of storage } \\
\qquad\left({ }^{\circ} \mathrm{C}\right)\end{array}$ & $\mathrm{ABA}$ & Heat-shock & $\begin{array}{l}\text { Air-dried to } 0.64 \mathrm{~g} \mathrm{~g}^{-1} \text { after } 14 \mathrm{~d} \text { of } \\
\text { storage }+ \text { sealed storage }\end{array}$ \\
\hline \multicolumn{5}{|c|}{ Experiment 1 (partial dehydration: $1.35 \rightarrow 1.02 \mathrm{~g} \mathrm{~g}^{-1}+$ sealed storage) } \\
\hline 1 & 5 & - & + & - \\
\hline 2 & 5 & - & - & - \\
\hline 3 & 20 & - & - & - \\
\hline \multicolumn{5}{|c|}{ Experiment 2 (moist storage in PEG) } \\
\hline 4 & 5 & - & + & + \\
\hline 5 & 5 & - & + & - \\
\hline 6 & 5 & - & - & + \\
\hline 7 & 5 & - & - & - \\
\hline 8 & 5 & + & + & + \\
\hline 9 & 5 & + & + & - \\
\hline 10 & 5 & + & - & + \\
\hline 11 & 5 & + & - & - \\
\hline 12 & 20 & - & - & + \\
\hline 13 & 20 & - & - & - \\
\hline 14 & 20 & + & - & + \\
\hline 15 & 20 & + & - & - \\
\hline
\end{tabular}

(Faria et al., 2004). The dried embryos were then put into aluminized plastic bags (sealed conditions, as in Experiment 1) and transferred back to their original temperatures $\left(5\right.$ or $\left.20^{\circ} \mathrm{C}\right)$. The other half of the stored embryos remained in PEG solutions. Experiment 2 was therefore composed of 12 treatments (Table 1). Nonstored embryos (control) and embryos stored for 14, 30 and $50 \mathrm{~d}$ were sampled for germination test, moisture content assessment and cytological studies (light and scanning electron microscopy). Based on the results of 2004, more seeds were collected in 2005 and treatments 7 , 11,13 and 15 (Table 1) were repeated. Non-stored embryos (control) and embryos stored for $30 \mathrm{~d}$ (treatments 7, 11, 13 and 15) and $62 \mathrm{~d}$ (treatment 15) were sampled for germination test, MC assessment and transmission electron microscopy.

Cytological analysis: For all cytological studies, three to five embryonic axes per treatment were excised from the embryos and fixed by immersion for $24 \mathrm{~h}$ in a modified Karnovsky solution (2.5\% glutaraldehyde, $2 \%$ formaldehyde in $50 \mathrm{mM}$ sodium cacodylate buffer, $1 \mathrm{mM}$ $\mathrm{CaCl}_{2}$, at $\mathrm{pH}$ 7.2). Thereafter different protocols were followed, depending on the microscopy technique, as described below.

Scanning Electron Microscopy (SEM): Samples were transferred to a cryo-protectant solution $(30 \%(\mathrm{v} / \mathrm{v})$ aqueous glycerol) for $30 \mathrm{~min}$ and sectioned longitudinally in liquid nitrogen using a scalpel blade. Sections were transferred to a $1 \%$ aqueous solution of osmium tetroxide for $1 \mathrm{~h}$ at room temperature and subsequently dehydrated in an increasing series of acetone solutions. Dehydrated samples were critical-point dried. Specimens were mounted on aluminum stubs, sputter-coated with gold and observed with a scanning electron microscope (LEO Evo40 XVP - Leo Electron Microscopy, Cambridge, UK). Observations were always made in the meristematic region of the radicle. 
Transmission Electron Microscopy (TEM): Samples were rinsed three times with $50 \mathrm{mM}$ cacodylate buffer, post-fixed in a $1 \%$ aqueous solution of osmium tetroxide, rinsed three times with $\mathrm{MQ} \mathrm{H}_{2} \mathrm{O}$, stained in uranyl acetate $(0.5 \%)$ and subsequently dehydrated in an increasing series of acetone solutions. The dehydrated tissue was gradually infiltrated with Spurr resin/acetone and embedded in pure Spurr resin and polymerized at $68^{\circ} \mathrm{C}$ for $48 \mathrm{~h}$. Thin sections $(<100 \mathrm{~nm})$ were cut in a Reichert-Jung (ultracut) ultramicrotome equipped with a diamond knife, picked up on copper slot grids, and allowed to dry onto Formvar-coated aluminum racks (Rowley and Moran, 1975). Sections were post-stained with uranyl acetate followed by lead citrate ( $3 \mathrm{~min}$ each) and examined using a transmission electron microscope (Zeiss EM 109, Carl Zeiss, Jena, Germany). Observations were made of cells in the radicle meristem.

\section{RESULTS}

\section{Moisture content}

Experiment 1 - Embryos stored partially dried: During $30 \mathrm{~d}$ of storage, MC showed a slight increase, if any, in the three treatments, from about 1.05 to $1.25 \mathrm{~g} \mathrm{~g}^{-1}$ (Figure 1A).

Experiment 2 - Embryos stored moist in PEG: The MC of the embryos at the beginning of the storage experiment performed in 2004 was $1.35 \mathrm{~g} \mathrm{~g}^{-1}$. Embryos removed from PEG at $14 \mathrm{~d}$ of storage, dehydrated to $0.64 \mathrm{~g} \mathrm{~g}^{-1}$ and stored again in plastic bags did not show subsequent significant changes of MC (data not shown). In embryos that were not dried and remained in PEG, MC varied differently among treatments, increasing or decreasing, depending on the treatment (Figure 2A) and sometimes on the seed batch (data not shown). The MC of seeds stored at $5^{\circ} \mathrm{C}(+\mathrm{ABA}$, with or without HS) was consistently and significantly lower than the $\mathrm{MC}$ of seeds stored in the absence of ABA. In contrast, ABA led to significantly higher $\mathrm{MC}$ at $20^{\circ} \mathrm{C}$. Both the $\mathrm{ABA}$ effects at $5^{\circ} \mathrm{C}$ and at $20^{\circ} \mathrm{C}$ were visible after 14,30 and $50 \mathrm{~d}$ of storage (Figure 2A). In 2005 no significant effects of ABA on MC were observed (data not shown).

\section{Germination}

Experiment 1 - Embryos stored partially dried (at sealed conditions): After $14 \mathrm{~d}$ of storage of partially dehydrated embryos at sealed conditions, germination dropped from $100 \%$ to less than $20 \%$ for those stored at $20^{\circ} \mathrm{C}$ and remained high (over 90\%) for those stored at $5^{\circ} \mathrm{C}$, regardless of $\mathrm{HS}$ treatments. However, after $30 \mathrm{~d}$ of storage, all seeds failed to germinate, irrespective of the storage temperature (Figure 1B). Embryos did not germinate during storage nor did they show any sign of degradation upon macroscopic inspection.

Experiment 2 - Embryos stored moist in PEG: After $14 \mathrm{~d}$ of storage in PEG, germination in all treatments was still high $(\approx 95 \%$; Figure $2 \mathrm{~B})$. In all treatments in which embryos were removed from PEG, dehydrated to $0.64 \mathrm{~g}$ $\mathrm{g}^{-1}$ after $14 \mathrm{~d}$ of storage and stored again in plastic bags at
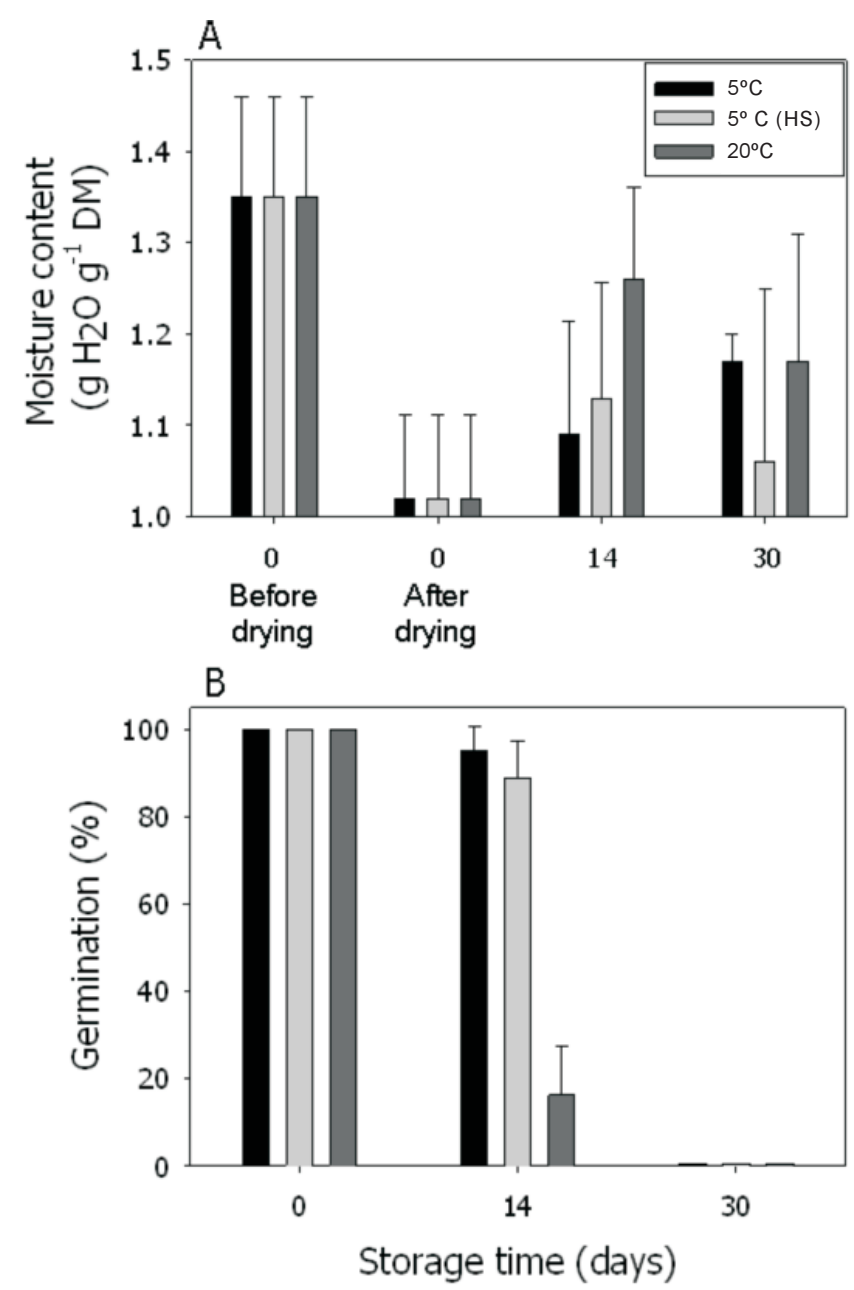

Figure 1. Moisture content (A) and germination (B) of partially dried Inga vera embryos after sealed storage (Experiment 1). Averages are from four replications of 20 embryos. Bars represent SD. 

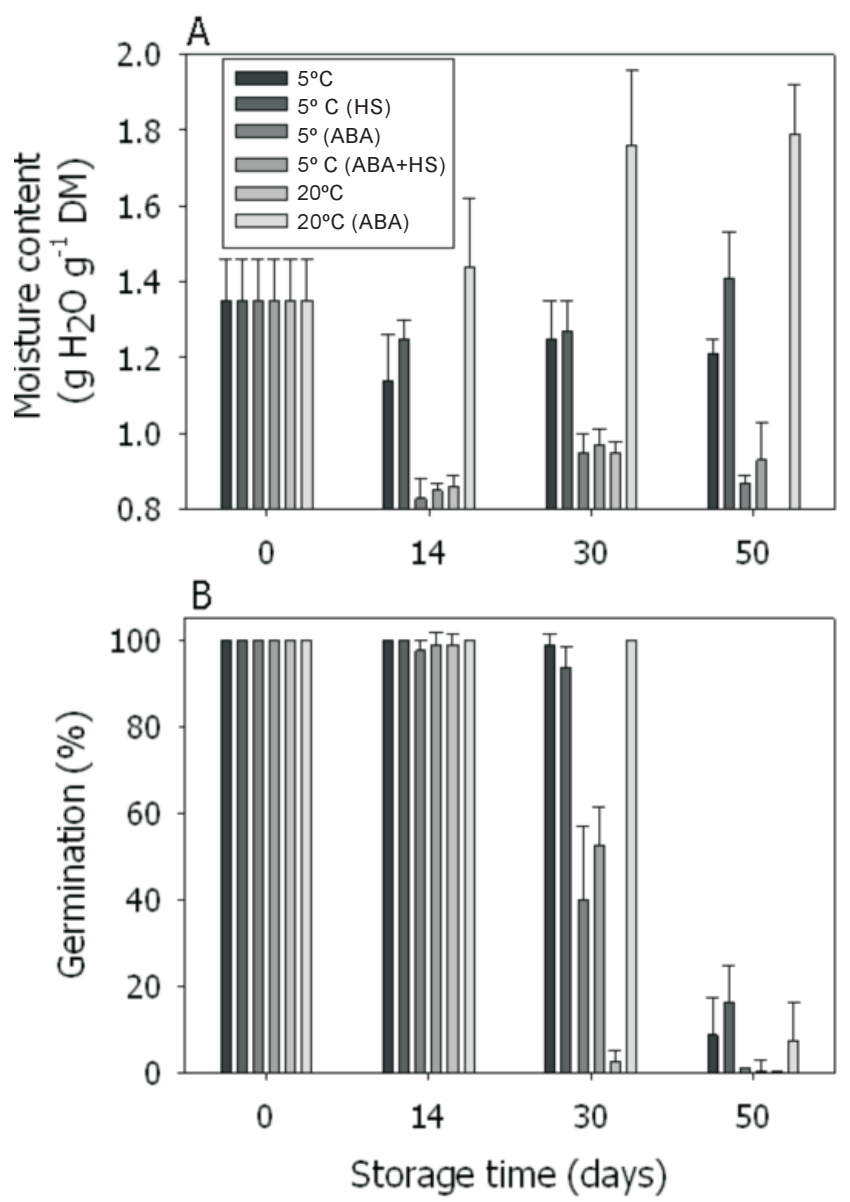

Figure 2. Moisture content (A) and germination (B) of Inga vera embryos (2004) after storage in PEG solution (Experiment 2) at different temperatures, with or without ABA or heat-shock (HS). Averages are from four replications of 20 embryos. Bars represent SD.

sealed conditions, there was an almost total loss of viability (less than $10 \%$ of germination) in the assessment done at $30 \mathrm{~d}$ of storage (data not shown). The only treatment not subjected to dehydration and sealed storage (Figure 2B) that also showed an almost complete loss of viability at $30 \mathrm{~d}$, was that of embryos stored at $20^{\circ} \mathrm{C}$ : under these conditions metabolic activity is also supposed to be high. In the same evaluation, embryos stored at $20^{\circ} \mathrm{C}$ with $\mathrm{ABA}$ attained maximum germination (100\%) like fresh, non-stored embryos (Figure 2B). High germination (over 94\%) was also observed in embryos stored at $5^{\circ} \mathrm{C}$ (without $\mathrm{ABA}$, regardless of HS treatments). Embryos stored at $5^{\circ} \mathrm{C}$ with ABA attained $53 \%$ (with HS) and $40 \%$ (without $\mathrm{HS}$ ) of germination in the evaluation done $30 \mathrm{~d}$ after the beginning of the storage. There was a clear relationship between $\mathrm{MC}$ (Figure $2 \mathrm{~A}$ ) and germination after $30 \mathrm{~d}$ of storage (Figure 2B). In the final evaluation, at $50 \mathrm{~d}$, the only treatments still showing some germination, albeit at low levels, ranging from 8 to $16 \%$, were storage at $5^{\circ} \mathrm{C}$ without $\mathrm{ABA}$ and at $20^{\circ} \mathrm{C}$ with $\mathrm{ABA}$ (Figure 2B). Again, there were similarities with the $\mathrm{MC}$ at $50 \mathrm{~d}$ of storage. When part of the experiment was carried out again in 2005 to generate samples for TEM visualization, the results of storability were in general better than in the previous year. The four treatments that were repeated $\left(5^{\circ} \mathrm{C}, 5^{\circ} \mathrm{C}+\mathrm{ABA}, 20^{\circ} \mathrm{C}\right.$ and $\left.20^{\circ} \mathrm{C}+\mathrm{ABA}\right)$ attained over $80 \%$ germination after $30 \mathrm{~d}$ of storage in PEG (data not shown). Embryos stored at $20^{\circ} \mathrm{C}$ with ABA reached $45 \%$ germination after $62 \mathrm{~d}$ of storage. Because the storage experiment made in 2005 was based on the results of the previous year, only a limited number of embryos was stored enough for evaluation (germination, moisture content and TEM visualization) at $30 \mathrm{~d}\left(5^{\circ} \mathrm{C}, 5^{\circ} \mathrm{C}\right.$ $+\mathrm{ABA}$ and $\left.20^{\circ} \mathrm{C}\right)$ and $62 \mathrm{~d}\left(20^{\circ} \mathrm{C}+\mathrm{ABA}\right)$ of storage. For this reason the experiment could not be extended to determine when embryos from 2005 would completely lose viability.

Cytological observations in stored embryos: SEM observations suggested that the abundance of starch granules in radicle cells declined as storage progressed (Figure 3). For example, most cells from embryonic axes of non-stored fresh embryos contained abundant starch granules (Figure $3 \mathrm{~A}$ ) whereas cells after $50 \mathrm{~d}$ of storage at $20^{\circ} \mathrm{C}$ in PEG + ABA generally appeared empty (Figure 3B).

Micrographs (TEM) of axis cells of the fresh control embryos generally showed that full-grown Inga seeds are still metabolically active, as can be expected for such a very recalcitrant species. The typical picture emerges of a metabolically active and viable cell, with polysomes and a round nucleus with dense nucleolus and peripherally arranged heterochromatin (Figure 4A). Mitochondria and amyloplasts (Figure 4B) were present in large numbers. Axis cells of embryos stored moist in PEG showed various changes, including confluence of lipid droplets resulting in large lipid masses in the cytoplasm and loss of cellular structure (Figure 4C). More severely damaged cells appeared totally devastated with cell wall folding, fragmented cytoplasm and amorphous nuclei (Figure 4D). In the same tissues and under the same storage conditions both healthy appearing cells and cells 

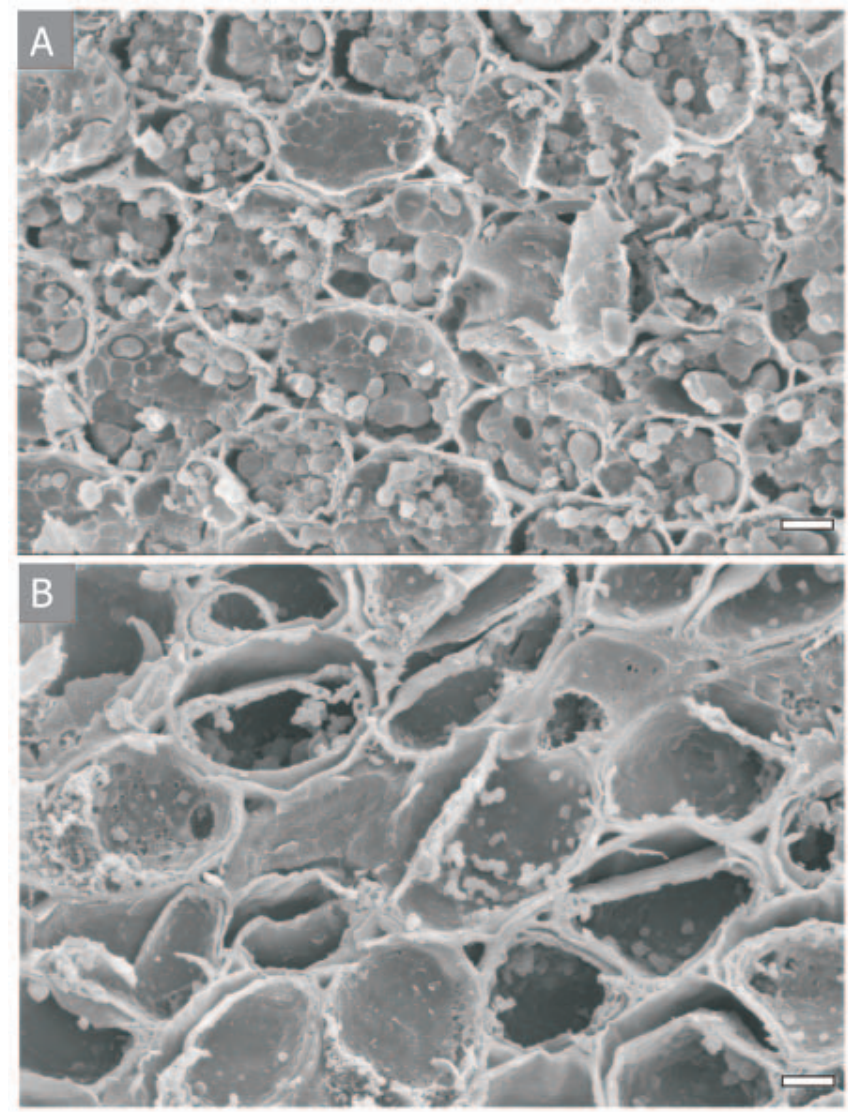

Figure 3. Scanning electron micrographs of embryonic axes from stored Inga vera embryos. (A) Control, nonstored, fresh embryos (100\% germination); (B) embryos stored in $\mathrm{PEG}+\mathrm{ABA}$ at $20^{\circ} \mathrm{C}$ for $50 \mathrm{~d}(7.5 \%$ germination $)$. Bars $=10 \mu \mathrm{m}$.

damaged to various degrees were observed next to each other. Because of the limited number of observations we could not correlate the extent of the damage or the number of damaged cells to the viability of the whole embryo, as assessed by the germination tests.

\section{DISCUSSION}

Just after processing, MC of the embryos of $I$. vera was $1.35 \mathrm{~g} \mathrm{~g}^{-1}$, which corresponds to a water potential close to $0 \mathrm{MPa}$ (Faria et al., 2004). During storage in PEG, with a water potential of -1.7 MPa, it was expected that in all treatments embryos would lose water to the osmotic medium, thus becoming to some extent dehydrated. This was indeed the case in embryos stored in PEG at $5^{\circ} \mathrm{C}$ with $\mathrm{ABA}$, at $5^{\circ} \mathrm{C}$ with $\mathrm{ABA}$ and $\mathrm{HS}$ and at $20^{\circ} \mathrm{C}$ without $\mathrm{ABA}$ or HS. However, a significant increase in $\mathrm{MC}$ was

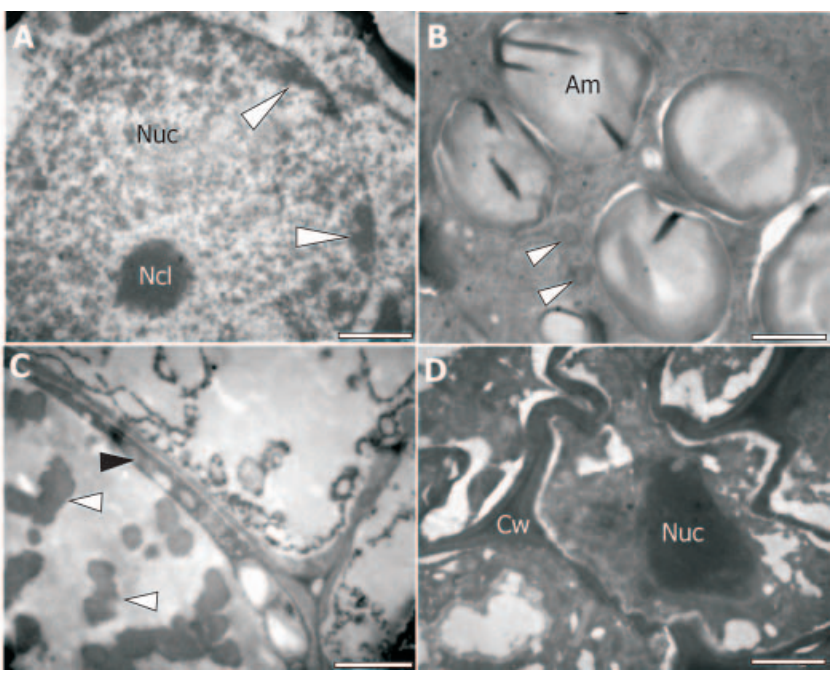

Figure 4. Transmission electron micrographs of embryonic axes from non-stored (A, B) and stored (C, D) Inga vera embryos. (A) Round nucleus (Nuc) with dense nucleolus ( $\mathrm{Ncl}$ ) and heterochromatin arranged peripherally (arrowheads); (B) amyloplasts (Am) and mitochondria (arrowheads) with normal appearance; (C) confluence of lipid droplets resulting in large masses in the cytoplasm (white arrowheads) and in the extraprotoplasmic space (black arrowhead); (D) more severely damaged cell, showing cell wall (Cw) folding, cytoplasm degradation and amorphous nucleus (Nuc). Bars: $\mathbf{A}=5 \mu \mathrm{m} ; \mathbf{B}-\mathbf{D}=10 \mu \mathrm{m}$.

observed with storage in PEG $+\mathrm{ABA}$ at $20^{\circ} \mathrm{C}$ after 20 and $50 \mathrm{~d}$ of storage. Intense respiration of stored recalcitrant seeds, which generates water, can increase MC during storage, Pritchard, 1998). In our experiments the unfavourable effect of oxygen depletion during sealed storage may have masked a possible positive effect of partial dehydration on the storability.

The longest effective storage period for Inga embryos was reported by Andréo et al. (2006) working with nondried embryos stored in PEG. They showed that the embryos were still able to reach $75 \%$ germination after 90 $\mathrm{d}$ of storage either at -1.6 or $-2.4 \mathrm{MPa}$ water potentials. In the present work, for the embryos stored moist in PEG, effects of the treatments were apparent after $30 \mathrm{~d}$ of storage. Abscisic acid completely prevented the loss of viability of embryos stored at $20^{\circ} \mathrm{C}$ but displayed a moderately negative effect on the viability of embryos stored at $5^{\circ} \mathrm{C}$. The efficacy of ABA in extending the 
storage life span of recalcitrant seeds depends on maturity status (Barbedo and Cícero, 2000) and whether or not the seeds are responsive to it (Berjak and Pammenter, 2003). Our results suggest that the efficacy of $\mathrm{ABA}$ is also dependent on the storage temperature. The use of exogenous ABA in recalcitrant seeds to improve storability has generally shown positive results for various species [e.g., Melicoccus bijugatus and Eugenia brasiliensis (Goldbach, 1979); Avicennia marina (Pammenter et al., 1997), Inga uruguensis (Barbedo and Cícero, 2000) and Acer saccharinum (Marshall et al., 2000)]. Absence of ABA effect was reported for Virola guatemalensis (Gonzalez and Fisher, 1997). Therefore, in addition of being dependent of the conditions of the experiments (seed maturity status, ABA concentration and storage temperature), effect of $\mathrm{ABA}$ on recalcitrant seed storage seems to be species-specific.

The HS treatment caused no significant effect on the storability at $5^{\circ} \mathrm{C}$ of moist-stored I. vera embryos. Incubation in PEG, slow drying and HS independently increased longevity of primed seeds of Impatiens walleriana (Bruggink et al., 1999). The heat-shock treatment was most effective at the highest MC of these seeds. Intermittent HS treatment has also been used to improve fruit storability of (recalcitrant) species, such as mango and avocado (Marcellin, 1992). This treatment was applied to reduce or prevent cold damage to the fruits by allowing repair processes to proceed at the intermittent elevated temperature. Although these treatments suggest having the potential to decrease the desiccation sensitivity shown by recalcitrant seeds and/or increase their longevity, their effectiveness remains to be demonstrated.

Re-establishment of desiccation tolerance in germinated Impatiens walleriana and Medicago truncatula seeds was accompanied by an increase in sucrose content (Bruggink et al., 1999; Buitink et al., 2003). The likely source of sucrose synthesis is starch, which is a common food reserve in seeds. Thus, apart from a role as energy source in the metabolically active embryos during moist storage, starch hydrolysis could also produce the sucrose necessary for the reduction of desiccation sensitivity. However, in the present study there was no direct relationship between disappearance of starch and reduction of desiccation sensitivity, at least at the moisture content reached $\left(0.64 \mathrm{~g} \mathrm{~g}^{-1}\right)$ after dehydration of stored embryos. Seeds of Castanea sativa have a high content of sucrose but are recalcitrant, suggesting that although sucrose may play a protective role in desiccation tolerance, it is not per se sufficient to confer survival to dehydration (Steadman et al., 1996) In many species starch is the last reserve material to be degraded during germination (Werker, 1997). Because recalcitrant embryos are in a germination mode of development it seems plausible that they use starch to maintain their energy metabolism during moist storage and that low temperatures slow down metabolism. Starch mobilization has also been reported in the integument of early developing Brassica napus seeds, when it undergoes programmed cell death (Wan et al., 2002). Based on the SEM images, disappearance of starch granules correlated with the decline of viability during storage of I. vera embryos. Abscisic acid did not affect starch degradation but it affected viability negatively at $5^{\circ} \mathrm{C}$ and positively at $20^{\circ} \mathrm{C}$ when stored in PEG. Thus, low temperature and $\mathrm{ABA}$ may affect viability by different mechanisms.

Various features observed in embryonic cells from the control treatment, such as numerous mitochondria and polysomes and well organized rER are indicators of ongoing metabolism and progress to germination as might be expected in newly-shed recalcitrant seeds (Berjak et al., 1993; Kioko et al., 1998). Most of these characteristics were also observed in stored embryos, but with the simultaneous occurrence of sub-cellular damages that have been associated with viability loss during storage of recalcitrant seeds (Berjak et al., 1993). A correlation between the extent of cellular damages and viability seems obvious but is difficult to demonstrate. This correlation may depend on cell type, the number of cells within the axis with non-repairable damage, as well as the number of non-viable embryos within the population that is used for the viability assessment.

Seeds collected in 2005 and stored in PEG performed better than those of 2004 as they were still able to germinate for $45 \%$ after $62 \mathrm{~d}$ of storage. In one single species the characteristics of mature seeds may vary from year to year within provenances, due to environmental factors and plant reproductive strategies. The best known examples are related to seed production (Kelly and Sork, 2002; Greene and Johnson, 2004), seed mass (Leishman et al., 2000) and seed dormancy (Baskin and 
Baskin, 1998). However there is a scarcity of such studies concerning desiccation sensitivity and storability. Tompsett and Pritchard (1993) showed that germination of mature Aesculus hippocastanum seeds collected from the same trees in two successive years decreased from 77 to $17 \%$ when dried to a MC of $c a .0 .43 \mathrm{~g} \mathrm{~g}^{-1}$. Such a yearto-year variation was also shown in relation to the storability of recalcitrant seeds of Machilus kusanoii: after four months of wet storage, germination of mature seeds decreased from $c a$. 100 to below $10 \%$, while in the next year, seeds collected from the same tree and stored for the same period under the same conditions, maintained germinability close to $100 \%$ (Chien and Lin, 1997). It is likely that in the present study the different results of storability of $I$. vera embryos attained with seeds collected in 2005, compared to 2004, were due to this natural variation.

For germplasm conservation purposes, seeds need to be stored for periods longer than those from sowing to sexual maturity of the plant (Roberts and King, 1980a,b). Inga vera trees start to bear fruits three to four years after planting, which is much longer than the storability achieved in the present study. Therefore, there is still an urgent need to develop techniques that lengthen substantially the viability of stored $I$. vera and recalcitrant seeds in general. Since recalcitrant seeds usually lack developmental arrest after maturation, storage protocols should aim at suppressing metabolic activity during moist storage. From our results it appeared that this will not easily be achieved by partial dehydration in combination with sealed storage. Storage under controlled atmosphere, common in long-term conservation of fresh fruits, may prove successful. Treatments with osmotic agents, such as PEG, or HS, which have proven successful in re-induction of desiccation tolerance or extension of longevity of germinated orthodox seeds (Bruggink and van der Toorn, 1995; Bruggink et al., 1999; Faria et al., 2005) were not effective. Polyethylene glycol may be used as a means to slow down metabolism rather than inducing desiccation tolerance. Application of growth regulators, such as ABA requires further study since it seems that $\mathrm{ABA}$ is able to extend storability of $I$. vera embryos, depending on the storage temperature. In addition, it is possible that mature recalcitrant seeds have completely lost unique seed traits such as desiccation tolerance and should therefore be regarded as vegetatively growing plants rather than seeds.

Acknowledgements: We thank CNPq (National Council for Scientific and Technological Development, from the Ministry of Science and Technology, Brazil) for financial support of the studies of J.M.R. Faria. The technical staff from the Laboratory of Forest Tree Seeds (Lavras Federal University - UFLA) is acknowledged for performing seed collection and handling. We also thank professor Eduardo Alves (Department of Plant Pathology, UFLA) for his assistance with the microscopy studies.

\section{REFERENCES}

Andréo Y, Nakagawa J, Barbedo C.J. (2006) Mobilização de água e conservação da viabilidade de embriões de sementes recalcitrantes de ingá (Inga vera Willd. subsp. affinis (DC.) T.D. Pennington). Rev. Bras. Bot. 29:309318.

Barbedo CJ, Cícero SM (2000) Effects of initial quality, low temperature and ABA on the storage of seeds of Inga uruguensis, a tropical species with recalcitrant seeds. Seed Sci. Technol. 28:793-808.

Baskin CC, Baskin JM (1998) Seeds: Ecology, Biogeography, and Evolution of Dormancy and Germination. Academic Press, San Diego.

Berjak P, Vertucci CW, Pammenter NW (1993) Effects of developmental status and dehydration rate on characteristics of water and desiccation-sensitivity in recalcitrant seeds of Camellia sinensis. Seed Sci. Res. 3:155-166.

Berjak P, Pammenter NW (2003) Understanding and handling desiccation-sensitive seeds. In: Smith RD, Dickie JB, Linington SH, Pritchard HW, Probert RJ (eds), Seed Conservation - Turning Science into Practice, pp.417-430. Royal Botanic Gardens, Kew.

Bewley JD, Black M (1994) Seeds. Physiology of Development and Germination. $2^{\text {nd }}$ ed. Plenum Press, New York

Bilia DAC, Marcos Filho J, Novembre ADCL (1998) Conservação da qualidade fisiológica de sementes de Inga uruguensis Hook. et Arn. Rev. Bras. Sem. 20:48-54.

Bilia DAC, Marcos Filho J, Novembre ADCL (1999) Desiccation tolerance and seed storability of Inga uruguensis (Hook. et Arn.). Seed Sci. Technol. 27:77-89.

Bilia DAC, Barbedo CJ, Cícero SM, Marcos Filho J (2003) Ingá: uma espécie importante para recomposição vegetal em florestas ripárias, com sementes interessantes para a ciência. Inf. Abrates 13:26-30.

Bruggink T, van der Toorn P (1995) Induction of 
desiccation tolerance in germinated seeds. Seed Sci. Res. 5:1-4.

Bruggink GT, Ooms JJJ, van der Toorn P (1999) Induction of longevity in primed seeds. Seed Sci. Res. 9:49-53.

Buitink J, Vu BL, Satour P, Leprince O. (2003) The reestablishment of desiccation tolerance in germinated radicles of Medicago truncatula Gaertn. seeds. Seed Sci. Res. 13:273-286.

Chien CT, Lin TP (1997) Effect of harvest date on the storability of desiccation-sensitive seeds of Machilus kusanoi Hay. Seed Sci. Technol. 25:361-371.

Chin HF (1989) Recalcitrant seeds. Extension Bulletin no. 288. ASPAC: Food and Fertilizer Technology Center, Taipei City.

Delseny M, Gaubier P, Hull G, Saez-Vasquez J, Gallois P, Raynal M, Cooke R, Grellet F (1994) Nuclear genes expressed during seed desiccation: relationship with responses to stress. In: Basra AS (ed), Stress-Induced Gene Expression in Plants, pp.25-59. Harwood Academic Publishers, Switzerland.

Drew PJ, Pammenter NW, Berjak P (2000) "Sub-imbibed" storage is not an option for extending longevity of recalcitrant seeds of the tropical species Trichilia dregeana Sond. Seed Sci. Res. 10:355-363.

Ellis RH, Hong TD, Roberts EH (1990) An intermediate category of seed storage behaviour? I. Coffee. J. Exp. Bot. 41:1167-1174.

Faria JMR, van Lammeren AAM, Hilhorst HWM (2004) Desiccation sensitivity and cell cycle aspects in seeds of Inga vera subsp. affinis. Seed Sci. Res. 14:165-178.

Faria JMR, Buitink J, van Lammeren AAM, Hilhorst HWM (2005) Changes in DNA and microtubules during loss and re-establishment of desiccation-tolerance in germinating Medicago truncatula seeds. J. Exp. Bot. 56:2119-2130.

Farrant JM, Berjak P, Pammenter NW (1993) Studies on the development of the desiccation-sensitive (recalcitrant) seeds of Avicennia marina (Forssk.) Vierh.: the acquisition of germinability and response to storage and dehydration. Ann. Bot. 71:405-410.

Ferreira SAN, Gentil DFO (2003) Armazenamento de sementes de camu-camu (Myrciaria dubia) com diferentes graus de umidade e temperaturas. Rev. Bras. Frut. 25:440-442.

Figliolia MB, Kageyama PY (1994) Maturação de sementes de Inga uruguensis Hook. et Arn. em floresta ripária do Rio Moji Guaçu, município de Moji Guaçu, SP. Rev. Inst. Flor. 6:13-52.

Goldbach H (1979) Imbibed storage of Melicoccus bijugatus and Eugenia brasiliensis (E. dombeyi) using abscisic acid as a germination inhibitor. Seed Sci. Technol. 7:403-406.
González JE, Fisher RF (1997) Effect of desiccation, temperature, and moisture content on seed storage of three tropical tree species. For. Sci. 43:595-601.

Greene DF, Johnson EA (2004) Modelling the temporal variation in the seed production of North American trees. Can. J. For. Res. 34:65-75.

Greggains V, Finch-Savage WE, Quick WP, Atherton NM (2000) Metabolism-induced free radical activity does not contribute significantly to loss of viability in moiststored recalcitrant seeds of contrasting species. New Phytol. 148:267-276.

Hong TD, Ellis RH (1998) Contrasting seed storage behaviour among different species of Meliaceae. Seed Sci. Technol. 26:77-95.

ISTA (International Seed Testing Association) (1996) International rules for seed testing. Seed Sci. Technol. 24 (suppl.).

Kang HM, Park KW, Saltveit ME (2005) Chilling tolerance of cucumber (Cucumis sativus) seedling radicles is affected by radicle length, seedling vigor, and induced osmotic- and heat-shock proteins. Physiol. Plant. 124:485-492.

Kelly D, Sork VL (2002) Mast seeding in perennial plants: Why, how, where? Annu. Rev. Ecol. Syst. 33:427-447

Kioko J, Berjak P, Pammenter NW, Watt PM, Wesley-Smith J (1998) Desiccation and cryopreservation of embryonic axes of Trichilia dregeana Sond. Cryo-Letters 19:15-26.

Köppen W (1936) Das geographische system der climate. In: Köppen W, Geiger R (eds), Handbuch der Klimatologie, Vol. 1, part C, pp.1-44. Gebrüder Borntraeger, Berlin.

Leishman MR, Wright IJ, Moles AT, Westoby M (2000) The evolutionary ecology of seed size. In: Fenner M (ed), Seeds: The Ecology of Regeneration in Plant Communities, $2^{\text {nd }}$ ed, pp.31-57. Cabi Publishing, Wallingford.

Leprince O, Harren FJM, Buitink J, Alberda M, Hoekstra FA (2000) Metabolic dysfunction and unabated respiration precede the loss of membrane integrity during rehydration of germinating radicles. Plant Physiol. 122:597-608.

Maluf AM, Bilia DAC, Barbedo CJ (2003) Drying and storage of Eugenia involucrata DC. seeds. Sci. Agric. 60:471-475.

Marcellin P (1992) Les maladies physiologiques du froid. In: Côme D (ed), Les Végétaux et le Froid, pp.53-105. Hermann, Paris.

Marshall J, Beardmore T, Whittle CA, Wang B, Rutledge RG, Blumwald E (2000) The effects of paclobutrazol, abscisic acid, and gibberellin on germination and early growth in silver, red, and hybrid maple. Can. J. For. Res. $30,557-565$. 
Marzalina M, Krishnapillay B (1999) Recalcitrant seed biotechnology applications to rain forest conservation. In: Benson EE (ed), Plant Conservation Biotechnology, pp.265-276. Taylor and Francis, London.

Okamoto JM, Joly CA (2000) Ecophysiology and respiratory metabolism during the germination of Inga sessilis (Vell.) Mart. (Mimosaceae) seeds subjected to hypoxia and anoxia. Rev. Bras. Bot. 23: 51-57.

Pammenter NW, Motete N, Berjak P (1997) The response of hydrated recalcitrant seeds to long-term storage. In: Ellis RH, Black M, Murdoch AJ, Hong TD (eds), Basic and Applied Aspects of Seed Biology, pp.673-687. Kluwer, Dordrecht.

Pammenter NW, Berjak P, Farrant JM, Smith MT, Ross G (1994) Why do stored hydrated recalcitrant seeds die? Seed Sci. Res. 4:187-191.

Roberts EH (1973) Predicting the storage life of seeds. Seed Sci. Technol. 1:499-514.

Roberts EH, King MW (1980a) The characteristics of recalcitrant seeds. In: Chin HF, Roberts EH (eds), Recalcitrant Crop Seeds, pp.1-5. Tropical Press, Kuala Lumpur.

Roberts EH, King MW (1980b) Storage of recalcitrant seeds. In: Withers LA, Williams JT (eds), Crop Genetic Resources: the Conservation of Difficult Material, pp.3948. IUBS/IGF/IBPGR, Paris.

Rowley CR, Moran DT (1975) A simple procedure for mounting wrinkle-free sections on formvar-coated slot grids. Ultramicrotomy 1:151-155.

Smith RD, Dickie JB, Linington SH, Pritchard HW, Probert RJ (2003) An editorial perspective on seed conservation.
In: Smith RD, Dickie JB, Linington SH, Pritchard HW, Probert RJ (eds), Seed Conservation - Turning Science into Practice, pp.969-980. Royal Botanic Gardens, Kew.

Steadman K, Pritchard HW, Dey PM (1996) Tissue-specific soluble sugars in seeds as indicators of storage category. Ann. Bot. 77:667-674.

Tompsett PB (1984) The effect of moisture content and temperature on the seed storage life of Araucaria columnaris. Seed Sci. Technol. 12:801-816.

Tompsett PB (1985) The influence of moisture content and storage temperature on the viability of Shorea almon, Shorea robusta, and Shorea roxburghii seed. Can. J. For. Res. 15:1074-1079.

Tompsett PB, Pritchard HW (1993) Water status changes during development in relation to the germination and desiccation tolerance of Aesculus hippocastanum L. seeds. Ann. Bot. 71:107-116.

Tompsett PB, Pritchard HW (1998) The effect of chilling and moisture status on the germination, desiccation tolerance and longevity of Aesculus hippocastanum L. seed. Ann. Bot. 82:249-261.

Wan L, Xia Q, Qiu X, Selvaraj G (2002) Early stages of seed development in Brassica napus: a seed coat-specific cysteine proteinase associated with programmed cell death of the inner integument. Plant J. 30:1-10.

Werker E (1997) Seed Anatomy. Gebruder Borntraeger, Berlin.

Zuniga R (1996) Chemical treatment to improve the viability of recalcitrant inga seeds. Bedfordshire, Cranfield University, M.Sc. Thesis. 